\title{
Impact of Defective Turbocharging System on the Safety and Reliability of Large Marine Diesel Engine
}

\author{
M. Anantharaman ${ }^{1}$, R. Islam ${ }^{1}$, A. Sardar 1 , V. Garaniya ${ }^{1}$ \& F. Khan ${ }^{2}$ \\ ${ }^{1}$ Australian Maritime College, University of Tasmania, Launceston, Australia \\ ${ }^{2}$ Memorial University of Newfoundland, St. John's, NL, Canada
}

\begin{abstract}
Today huge capacity sea-going vessels are propelled by mega high-powered marine diesel engines, referred to as Main Engine. Turbocharging system is an integral part of large marine diesel engine plant, contributing to their safety, reliability, and efficiency. Defects in the turbocharging system could result in higher fuel consumption, erratic running of the Main Engine, and in the worst scenario may result in the stoppage of the Main Engine at sea. An inefficient turbocharging system may also cause major damage to turbochargers, resulting in undesirable accidents out at sea. To avoid such undesirable accidents and ensure smooth operations of the Main Engine, it is required to address this concern. The aim of this research is to study the turbocharging system for a large Main Engine using a Kongsberg engine simulator. Various malfunction of the Turbocharging system is considered, relevant data is collected and analysed. Moreover, a Fault Tree Analysis, (FTA) is considered to identify the top undesirable event which is the failure of the Main Engine. Based on the results of this study, various steps are suggested to avoid failure of the Main Engine due to the defective turbocharging system.
\end{abstract}

\section{INTRODUCTION}

Reliability and safety of a large marine diesel engine hereafter referred to as Main Engine is dependent on the reliability of its sub-systems, which include the fuel oil system, lubricating oil system, cooling water system, and the turbocharging system [1, 2,9]. The turbocharging system forms a vital sub-system that mainly comprises turbochargers and air coolers, which form an integral part of turbocharging. This study investigates some aspects of the turbocharging process, the malfunction of which can lead to the failure of the Main Engine [6].

The Kongsberg Engine Room Simulator at the Australian Maritime College, the University of Tasmania in Australia is utilised to investigate various malfunctions of the Turbocharging system, collect relevant data, and draw useful conclusions.

All large Main Engines propelling huge vessels are two-stroke turbocharged engines, where the air for turbocharging is provided by 1 to 4 turbochargers depending on the engine capacity. The Main Engine in consideration for the simulation is MAN B\&W 5L90MC, with a cylinder bore of $90 \mathrm{~cm}$, piston stroke of $290 \mathrm{~cm}$ comprising of 5 cylinders, 2 air coolers and 2 turbochargers. The maximum continuous rating of the engine (MCR) is $17400 \mathrm{~kW}$, corresponding. engine speed is $76 \mathrm{rpm}$. The mean indicated pressure of each cylinder is 13.0 bar, scavenge air pressure being 2.1 bar. The turbocharger speed is $8000 \mathrm{rpm}$. The engine is attached to a 5 bladed propeller, the propeller pitch being 1.2. The engine burns fuel DO/ HFO $700 \mathrm{cSt}$, the specific fuel consumption $168 \mathrm{~g} / \mathrm{kwh}$ Turbocharger's 
form part of the scavenge sub-system and play a vital role in the operation of the main engine. Failure of turbochargers can lead to disastrous consequences and immobilisation of the Main Engine, [3]. Turbochargers for large Main Engine, would generally comprise of a single-stage axial-flow turbine coupled to a single-stage rotary compressor, driven by a common rotor shaft. The exhaust gases from the Main Engine drive the turbine which in turn drives the compressor. The compressor draws air from the engine room and is compressed to a higher pressure and temperature which can reach $200 \mathrm{degs} C$, which is then directed to the air cooler for cooling, prior to entering the scavenge manifold, from where the air is distributed to individual cylinders. A turbocharger on an engine bed plate is shown in Figure 1.

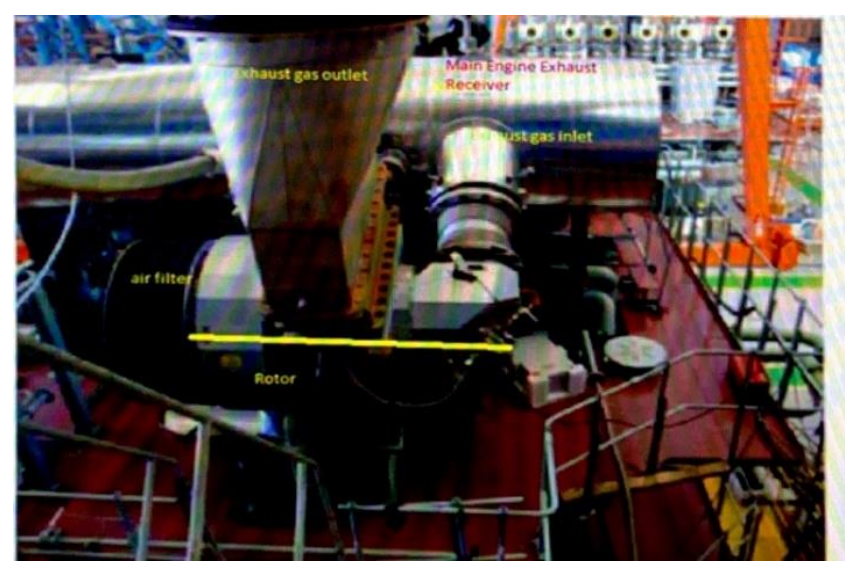

Figure 1. Turbocharger for a large two stroke engine at test bed [2].

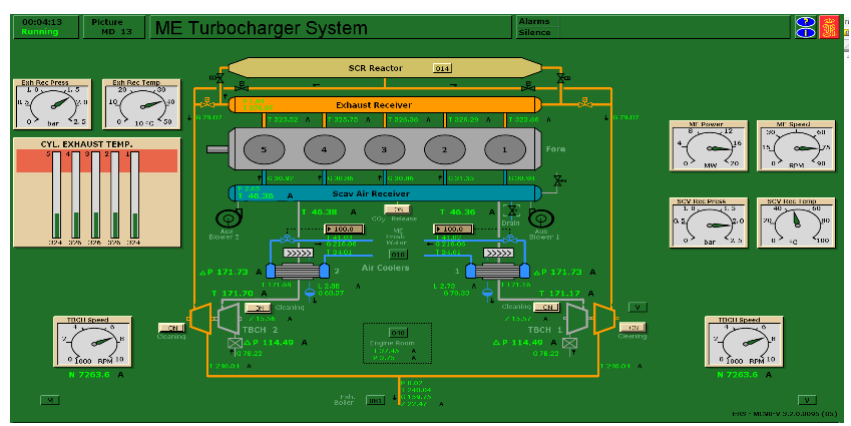

Figure 2. Main Engine Turbocharging system (Kongsberg Simulator at AMC), with dirty air filter. The red points indicated abnormal values.

The efficiency, safety, and reliability of the turbocharger depend on the efficiency of the turbine and compressor.

To evaluate the efficiency of the turbocharger, it is essential to evaluate the efficiency of the turbine and the compressor as given by MAN B\&W instructions for 50-89 MC type engines operation manual [4].

$\eta_{\text {total }}=\eta_{\text {ocompressor }} \times \eta_{\text {turbine }}$

It is vital that both the compressor side and the turbine side must be efficient for high turbocharging efficiency, as seeen in equation (1) above.

\section{ASSESSMENT OF MALFUNCTIONS IN THE TURBOCHARGING SYSTEM}

The Kongsberg Simulator is utilised to assess malfunctions in the turbocharging system. The compressor and turbine of the turbocharger are the two vital components that are responsible for the overall efficiency of the turbocharger, as evident from Equation1. The compressor is generally referred to as the airside of the turbocharger, whereas the turbine is referred to as the exhaust side of the turbocharger. Any malfunction on the air side or exhaust side leads to abnormal function of the turbocharger, which will affect the efficiency hence the reliability of the turbocharging system, which in turn will adversely affect the reliability of the Main Engine. Whilst there are a range of malfunctions that affect the turbocharging system, this paper would consider two malfunctions, one each on the air side and exhaust side and study its impact on the turbocharging system [10].

\subsection{Air filter dirty}

Air is drawn from the engine room atmosphere through air inlet filters. Air inlets are streamlined and fitted with insulation internally to reduce noise. The filters can be removed for cleaning. The quality and quantity of the intake air to the turbocharger depends to a very large extent on the condition of the air filters. It is essential that the filters be cleaned at regular intervals preferably every 500 hours of the engine running. At the same time, it is necessary that they are well protected in ports when the Main Engine is on stop. It is a normal practice to cover the filter casing with a canvass cover which would prevent intake of dust in ports, especially on bulk carriers loading coal, iron ore, or grain. It can thus avoid the intake of the cargo dust in port. Also, the blower trunk supplying air to the compressor could be isolated in port. Having isolated the blower, a notice to that effect should be clearly displayed at the prominent location for awareness of the engine room crew, at a local point and in the ECR (engine control room). Prior to the departure port, the blower can be put to normal use and the filter uncovered for Main Engine operation. Table.1 shows the Main Engine parameters before and after introducing the malfunction 'dirty air filter'.

\subsection{Inlet grid dirty}

Exhaust gases from the main engine exhaust manifold enter the turbocharger gas inlet casing via a protective exhaust grid. The function of the exhaust grid is to trap the unburnt carbon and coke particles from entering the turbine. The exhaust grid also traps any broken piston rings, broken valve components from entering the turbocharger gas inlet casing which apart from affecting the balancing of the turbocharger rotor, will also result in major damage to the turbocharger, and stoppage of the main engine which may result in a major accident of the vessel [5]. It is very important to periodically inspect the exhaust manifold and the exhaust inlet grid, to ensure that there are no foreign particles in the form of broken piston rings and 
similar components. The second malfunction in this study relates to the turbocharger1 dirty inlet grid. Table 2 below shows the parameters related to this malfunction.

Table 1. Main Engine TCH 1 dirty air filter

\begin{tabular}{|c|c|c|c|c|}
\hline Main Engine & Values & during $\mathrm{rl}$ & unning & \\
\hline Parameters & Units & $\begin{array}{l}\text { Clean } \\
\text { air } \\
\text { filter }\end{array}$ & $\begin{array}{l}\text { Dirty } \\
\text { air } \\
\text { filter }\end{array}$ & $\begin{array}{l}\text { \%Change } \\
\text { in } \\
\text { values }\end{array}$ \\
\hline $\begin{array}{l}\text { ME air receiver } \\
\text { pressure }\end{array}$ & bar & 2.05 & 2.01 & 2 \\
\hline $\begin{array}{l}\text { ME exh receiver } \\
\text { pressure }\end{array}$ & bar & 1.69 & 1.66 & 1.8 \\
\hline $\begin{array}{l}\text { ME air receiver } \\
\text { temperature }\end{array}$ & $\operatorname{deg} C$ & 46.37 & 46.08 & 0.6 \\
\hline $\begin{array}{l}\text { ME exh receiver } \\
\text { temperature }\end{array}$ & $\operatorname{deg} C$ & 371.00 & 377.80 & -1.8 \\
\hline ME TBCH 1 speed & rpm & 7265.27 & 7201.51 & 0.9 \\
\hline ME TBCH 1 air flow & ton $/ \mathrm{h}$ & 78.39 & 74.38 & 5.1 \\
\hline ME TBCH 1 exh flow & ton $/ \mathrm{h}$ & 79.87 & 77.57 & 2.9 \\
\hline $\begin{array}{l}\text { ME TBCH } 1 \text { exh } \\
\text { outlet temperature }\end{array}$ & $\operatorname{deg} C$ & 239.82 & 245.49 & -2.4 \\
\hline $\begin{array}{l}\text { ME TBCH } 1 \text { air } \\
\text { outlet temperature }\end{array}$ & $\operatorname{deg} C$ & 171.22 & 175.68 & -2.6 \\
\hline $\begin{array}{l}\text { ME TBCH } 1 \text { air filter } \\
\text { pressure drop }\end{array}$ & $\mathrm{mmWC}$ & 115.00 & 140.22 & -21.9 \\
\hline ME TBCH 2 speed & $\mathrm{rpm}$ & 7261.49 & 7210.58 & 0.7 \\
\hline ME TBCH 2 air flow & ton $/ \mathrm{h}$ & 78.12 & 77.72 & 0.5 \\
\hline ME TBCH 2 exh flow & ton $/ \mathrm{h}$ & 79.71 & 77.88 & 2.3 \\
\hline $\begin{array}{l}\text { ME TBCH } 2 \text { exh } \\
\text { outlet temperature }\end{array}$ & $\operatorname{deg} C$ & 239.81 & 245.45 & -2.4 \\
\hline $\begin{array}{l}\text { ME TBCH } 2 \text { air } \\
\text { outlet temperature }\end{array}$ & $\operatorname{deg} C$ & 171.71 & 169.67 & 1.2 \\
\hline
\end{tabular}

Table 2. Main Engine TCH 1 exhaust grid dirty

\begin{tabular}{|c|c|c|c|c|}
\hline Main Engine & Values & during ru & Anning & \\
\hline Parameters & Units & $\begin{array}{l}\text { Clean } \\
\text { grid }\end{array}$ & $\begin{array}{l}\text { Dirty } \\
\text { grid }\end{array}$ & $\begin{array}{l}\% \text { Change } \\
\text { in values }\end{array}$ \\
\hline $\begin{array}{l}\text { ME air receiver } \\
\text { pressure }\end{array}$ & bar & 2.05 & 1.78 & 13.2 \\
\hline $\begin{array}{l}\text { ME exh receiver } \\
\text { pressure }\end{array}$ & bar & 1.69 & 1.52 & 10.1 \\
\hline $\begin{array}{l}\text { ME air receiver } \\
\text { temperature }\end{array}$ & $\operatorname{deg} C$ & 46.37 & 44.21 & 4.7 \\
\hline $\begin{array}{l}\text { ME exh receiver } \\
\text { temperature }\end{array}$ & $\operatorname{deg} C$ & 371.00 & 486.25 & -31 \\
\hline ME TBCH 1 speed & $\mathrm{rpm}$ & 7265.27 & 6402.87 & 11.9 \\
\hline ME TBCH 1 air flow & ton $/ \mathrm{h}$ & 78.39 & 35.68 & 54.5 \\
\hline ME TBCH 1 exh flow & ton $/ \mathrm{h}$ & 79.87 & 54.55 & 31.7 \\
\hline $\begin{array}{l}\text { ME TBCH } 1 \text { exh } \\
\text { outlet temperature }\end{array}$ & $\operatorname{deg} C$ & 239.82 & 360.12 & -50.2 \\
\hline $\begin{array}{l}\text { ME TBCH } 1 \text { air } \\
\text { outlet temperature }\end{array}$ & $\operatorname{deg} C$ & 171.22 & 231.78 & -35.4 \\
\hline $\begin{array}{l}\text { ME TBCH } 1 \text { air filter } \\
\text { pressure drop }\end{array}$ & $\mathrm{mmWC}$ & 115.00 & 23.83 & 79.3 \\
\hline ME TBCH 2 speed & $\mathrm{rpm}$ & 7261.49 & 7061.20 & 2.8 \\
\hline ME TBCH 2 air flow & ton $/ \mathrm{h}$ & 78.12 & 81.30 & -4.1 \\
\hline ME TBCH 2 exh flow & ton $/ \mathrm{h}$ & 79.71 & 66.31 & 16.8 \\
\hline $\begin{array}{l}\text { ME TBCH } 2 \text { exh } \\
\text { outlet temperature }\end{array}$ & $\operatorname{deg} C$ & 239.81 & 333.61 & -39.1 \\
\hline $\begin{array}{l}\text { ME TBCH } 2 \text { air } \\
\text { outlet temperature }\end{array}$ & $\operatorname{deg} C$ & 171.71 & 160.94 & 6.3 \\
\hline $\begin{array}{l}\text { ME TBCH } 2 \text { air filter } \\
\text { pressure drop }\end{array}$ & $\mathrm{mmWC}$ & 114.21 & 123.69 & -8.3 \\
\hline
\end{tabular}

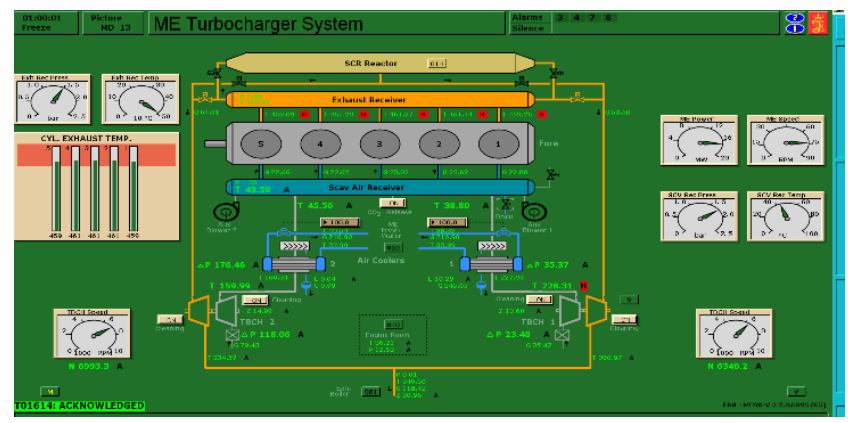

Figure 3. Main Engine Turbocharging system (Kongsberg Simulator at $\mathrm{AMC})$, inlet grid dirty.

\section{ANALYSIS OF SIMULATION}

\subsection{Dirty air filter}

In this engine, the turbocharger 1 air filter dirty malfunction was activated. The Main engine was run at full away speed for 10 minutes. It is seen in Table1, that the air pressure drops across this filter rose by $22 \%$. Apart from the pressure drop across the filter, there was no noticeable change in the other parameters of the turbocharging system. The turbocharger $1 \& 2$, exhaust outlet temperature ME $\mathrm{TBCH} 1$ rose by $2.4 \%$ to a value of $245.49 \mathrm{degs} \mathrm{C}$. The turbocharger 1 \& 2 air outlet temperature showed some difference. The turbocharger 1 air outlet temperature showed an increase of $2.6 \%$, whereas the turbocharger 2 air outlet temperature showed a reduction of $1.2 \%$. Hence apart from an increase in the air pressure drop across the filter, there was not much impact on the main engine operation. It can be seen from the Neptune log below (Table 3), that even after 49 minutes of running of the Main Engine the propeller speed remained the same at $74.0 \mathrm{rpm}$ However, it is advisable to replace the air filter elements at the earliest opportunity, which would prevent further deterioration of the filter element.

Table 3. PC: AMC-FSN83M2 - Neptune Log - 2/03/2021 11:00:48 AM

\begin{tabular}{|c|c|}
\hline Time & Event \\
\hline 00:00:00 & $\begin{array}{l}\text { Z07109 SET }=77 \% \text { SOUND LEVEL SETPOINT } \\
\text { (AMC-FSN83M2) }\end{array}$ \\
\hline 00:09:25 & DCMES: DO \\
\hline $00: 25: 09$ & DCMES: LO \\
\hline 00:43:04 & $\begin{array}{l}\text { T01601 [46.35 degC]: ME air receiver temp } \\
\text { (AMC-FSN83M2) }\end{array}$ \\
\hline 00:43:20 & $\begin{array}{l}\text { M2402 SET }=30 \% \text { ME TBCH } 1 \text { air filter dirty } \\
\text { (AMC-FSN83M2) }\end{array}$ \\
\hline 00:47:20 & $\begin{array}{l}\text { N03761 [74.00 rpm]: Propeller speed (AMC- } \\
\text { FSN83M2) }\end{array}$ \\
\hline $00: 47: 22$ & $\begin{array}{l}\text { T01613 [245.96 degC]: ME TBCH } 1 \text { exh outlet } \\
\text { temp (AMC-FSN83M2) }\end{array}$ \\
\hline 00:47:49 & $\begin{array}{l}\text { N03761 [74.00 rpm]: Propeller speed (AMC- } \\
\text { FSN83M2) }\end{array}$ \\
\hline $00: 47: 54$ & $\begin{array}{l}\text { N03761 [74.00 rpm]: Propeller speed (AMC- } \\
\text { FSN83M2) }\end{array}$ \\
\hline $00: 49: 23$ & $\begin{array}{l}\text { N03761 [74.00 rpm]: Propeller speed (AMC- } \\
\text { FSN83M2) }\end{array}$ \\
\hline
\end{tabular}




\subsection{Exhaust inlet dirty grid}

On examining Table 2 , above, the air receiver pressure (bar) reduced by $13.2 \%$. The corresponding percentage reduction in the exhaust receiver pressure (bar) is $10.1 \% /$. There was a minor reduction in the air receiver temperature ( $\mathrm{degC}$ ) by $4.7 \%$. On the contrary, there was a major increase in the temperature of the exhaust receiver (degC) by $31 \%$.

Since the exhaust grid of ME TBCH 1 was simulated as dirty, it can be noticed that this had an impact on the turbochargr1 $\mathrm{rpm}$ which reduced by $11.9 \%$, but the reduction in turbocharger $2 \mathrm{rpm}$ was much less at $2.8 \%$. The exhaust gas flow (ton/h) had reduced substantially by $31.7 \%$, leading to a great reduction in air flow (ton/h) by $54.5 \%$. The main engine turbocharger 1 exhaust temperature (egC) rose by $50.2 \%$, leading to a corresponding increase in air outlet temperature (deg C) by $35.4 \%$. Another notable point was the pressure drop across the turbocharger 1 air filter by $79.3 \%$.

It can be seen from Table 4, that the automatic slowdown of the engine took place 11 minutes after introducing the faulty condition.

It is essential to periodically check the exhaust manifold in port, after taking all safety precautions. Inspect for any broken piston rings, valves, or excessive carbon accumulation at the turbocharger inlet grid.

Table 4. PC: AMC-FSN83M2 - Neptune Log - 2/03/2021 12:13:41 PM

\begin{tabular}{ll}
\hline Time & Events \\
\hline $00: 04: 30$ & $\begin{array}{l}\text { Z07109 SET=77 \% SOUND LEVEL SETPOINT } \\
\text { (AMC-FSN83M2) }\end{array}$ \\
$00: 05: 21$ & $\begin{array}{l}\text { E02005 [16.76 MW]: ME shaft power (to } \\
\text { propeller) (AMC-FSN83M2) }\end{array}$ \\
00:05:25 & $\begin{array}{l}\text { N01620 [7258.65 rpm]: ME TBCH 2 speed } \\
\text { (AMC-FSN83M2) }\end{array}$
\end{tabular}

00:05:46 M2408 SET=70 \% ME TBCH 1 inlet grid dirty (AMC-FSN83M2)

00:07:05 T01614 234.83 HIGH [AG08] ME TBCH 1 air outlet temp

00:07:09 X07069 SET $=1<0$-2 $>$ ALARM STATE (AMCFSN83M2)

00:07:11 T01614 [234.41 degC]: ME TBCH 1 air outlet temp (AMC-FSN83M2)

00:07:12 T01614 ACKNOWLEDGE ME TBCH 1 air outlet temp (AMC-FSN83M2)

00:07:22 V20103 [CLOSED]: ME exh 1 SCR outlet valve (AMC-FSN83M2)

00:07:27 X01952 1 HIGH [AG03] ME slow down prewarning

00:07:32 T02100 460.56 HIGH [AG07] ME cyl 2 exh outlet temp

00:07:33 T02040 457.69 HIGH [AG07] ME cyl 1 exh outlet temp

00:07:33 T02100 [460.48 degC]: ME cyl 2 exh outlet temp (AMC-FSN83M2)

00:07:34 T02140 460.44 HIGH [AG07] ME cyl 3 exh outlet temp

00:07:34 T02100 ACKNOWLEDGE ME cyl 2 exh outlet temp (AMC-FSN83M2)

00:07:35 T02040 [457.63 degC]: ME cyl 1 exh outlet temp (AMC-FSN83M2)

00:07:36 T02040 ACKNOWLEDGE ME cyl 1 exh outlet temp (AMC-FSN83M2)

00:07:37 T02200 459.16 HIGH [AG07] ME cyl 4 exh outlet temp

00:07:37 T02140 [460.31 degC]: ME cyl 3 exh outlet temp (AMC-FSN83M2)
00:07:37

00:07:38

T02140 ACKNOWLEDGE ME cyl 3 exh outlet temp (AMC-FSN83M2)

T02200 [459.10 degC]: ME cyl 4 exh outlet temp (AMC-FSN83M2)

00:07:38 T02200 ACKNOWLEDGE ME cyl 4 exh outlet temp (AMC-FSN83M2)

00:07:39 T02240 [457.05 degC]: ME cyl 5 exh outlet temp (AMC-FSN83M2)

00:07:41 T02240 456.96 HIGH [AG07] ME cyl 5 exh outlet temp

00:07:41 T02240 [456.96 degC]: ME cyl 5 exh outlet temp (AMC-FSN83M2)

00:07:41 T02240 ACKNOWLEDGE ME cyl 5 exh outlet temp (AMC-FSN83M2)

00:07:44 X07069 SET $=1<0-2>$ ALARM STATE (AMCFSN83M2)

00:07:49 DCMES: SHAF

00:07:52 T01601 [44.21 $\mathrm{deg}$ ] ]: ME air receiver temp (AMC-FSN83M2)

00:07:55 N03761 [74.07 rpm]: Propeller speed (AMCFSN83M2)

00:08:01 N03761 [74.06 rpm]: Propeller speed (AMCFSN83M2)

00:08:03 T02106 206.48 HIGH [AG04] ME cyl 2 liner temp (mean)

00:08:11 T02105 262.24 HIGH [AG04] ME cyl 2 cover temp (mean)

00:08:17 T02145 262.72 HIGH [AG04] ME cyl 3 cover temp (mean)

00:08:19 T02205 262.04 HIGH [AG04] ME cyl 4 cover temp (mean)

00:08:25 T02045 260.27 HIGH [AG04] ME cyl 1 cover temp (mean)

00:08:33 T02146 203.24 HIGH [AG04] ME cyl 3 liner temp (mean)

00:08:33 T02245 261.25 HIGH [AG04] ME cyl 5 cover temp (mean)

00:08:39 T02206 203.03 HIGH [AG04] ME cyl 4 liner temp (mean)

00:08:57 T02046 202.70 HIGH [AG04] ME cyl 1 liner temp (mean)

00:09:05 T02246 202.76 HIGH [AG04] ME cyl 5 liner temp (mean)

00:09:25 DCMES: DO

00:11:04 X02445 2 HIGH [AG03] Autochief : Slow down

00:11:12 N01610 [6925.85 rpm]: ME TBCH 1 speed (AMC-FSN83M2)

00:11:12 N01610 [6925.85 rpm]: ME TBCH 1 speed (AMC-FSN83M2)

00:11:12 N01610 [6925.85 rpm]: ME TBCH 1 speed (AMC-FSN83M2)

00:11:12 T01601 [43.27 degC]: ME air receiver temp (AMC-FSN83M2)

00:11:12 N01610 [6925.85 rpm]: ME TBCH 1 speed (AMC-FSN83M2)

00:11:12 X07069 SET $=1<0-2>$ ALARM STATE (AMCFSN83M2)

\section{RELIABILITY ANALYSIS OF THE TURBOCHARGING SYSTEM}

This can be represented by means of a Fault Tree as shown in Figure 4. 


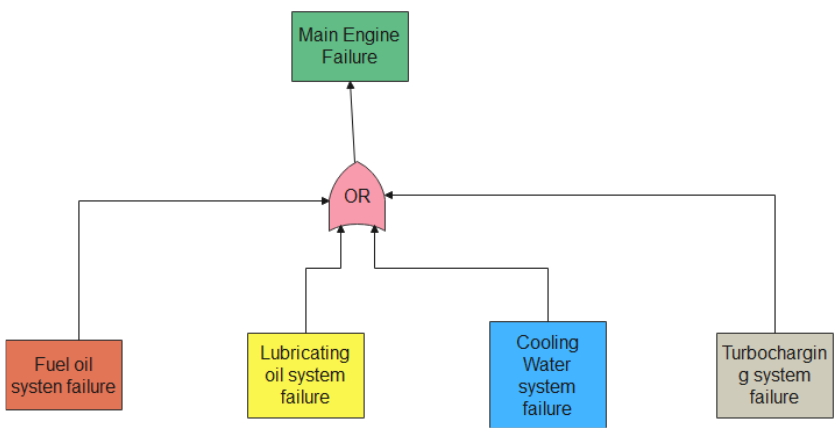

Figure 4. Fault Tree for failure of a Main Engine.

The above condition can be expressed by a reliability block diagram (RBD) [15].

The reliability of the Main Engine may be expressed by the following simple relationship [8].

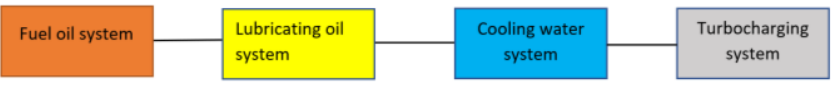

Figure 5. RBD for a Main Engine.

$R_{M E}=R_{F O} \times R_{L O} \times R_{C W} \times R_{T C}$

where,

$R_{M E}=$ Reliability of Main Engine,

$R_{F O}=$ Reliability of fuel oil system,

$R_{L O}=$ Reliability of lubricating oil system,

$R_{C W}=$ Reliability of the cooling water system and

$R_{T C}=$ Reliability of the Turbocharging system.

If any of the system shown in the RBD for the Main Engine fails, then it would result in the failure of the Main Engine [12].

The Reliability of the Main Engine can also be represented as

$$
\begin{aligned}
& R_{M E}=\prod_{i=1}^{4} R_{i} \\
& R_{F O}=1, \quad R_{L O}=2, R_{C W}=3 \& R_{T C}=4
\end{aligned}
$$

The fault tree for the Main Engine Turbocharging system is shown in Figure 6.

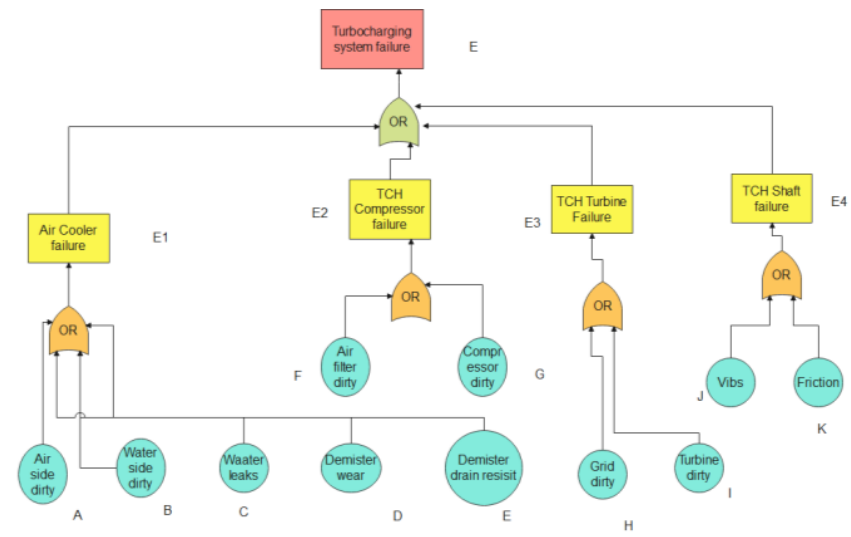

Figure 6. Fault Tree for Turbocharging system

\begin{tabular}{|c|c|c|c|c|}
\hline \multirow{2}{*}{$\begin{array}{c}\text { Air Cooler } \\
\text { E1 }\end{array}$} & $\begin{array}{c}\text { TCH Compressor } \\
\text { E2 }\end{array}$ & $\begin{array}{c}\text { TCH Turbine } \\
\text { E3 }\end{array}$ & \multicolumn{1}{c|}{$\begin{array}{c}\text { TCH Shaft } \\
\text { E4 }\end{array}$} \\
\hline
\end{tabular}

Figure 7. Reliability Block diagram (RBD) for a Main Engine Turbocharging system

$$
\begin{aligned}
& R_{T C}=\prod_{i=E 1}^{E 4} R_{i} \\
& R_{E 1}=\prod_{i=A}^{E} R_{i}=R_{A} * R_{B} * R_{C} * R_{D} * R_{E} \\
& R_{E 2}=\prod_{i=F}^{G} R_{i}=R_{F} * R_{G} \\
& R_{E 3}=\prod_{i=H}^{I} R_{i}=R_{H} * R_{I} \\
& R_{E 4}=\prod_{i=J}^{K} R_{i}=R_{J} * R_{K}
\end{aligned}
$$

It can be seen from the reliability block diagram in Figure. 1, that the reliability of the turbocharging system is dependent on the reliability of air cooler E1, turbocharger compressor E2, turbocharger turbine E3, and turbocharger shaft E4. E1, E2, E3 and E4 are in series. Hence the failure of any one of the components will result in the failure of the turbocharging system, which in turn will result in the failure of the main engine. Using the above method, the reliability of the turbocharging system R_TC may be computed. Details of this method will be taken up in further work on this topic.

The manufacturers of the main engine and turbochargers specify the time intervals for overhauling and maintenance of various components of the main engine and turbochargers. One of the important factors essential to compute the reliability of any system component is the time between failures, $[13,14]$. The time between overhauls may be taken as a useful guide to computing reliability [7].

Some sample values of overhaul intervals for the turbocharger given by a leading manufacturer are shown below [11].

Table 5. Turbocharger Maintenance schedule

\begin{tabular}{lc}
\hline Activity & Cleaning interval in hours \\
\hline Clean turbine - dry clean & 250 \\
Clean turbine - wet clean & 250 \\
Clean air filter & 250 \\
Clean and check compressor & 12000 \\
casing insert and compressor wheel & \\
Major overhaul & $24000-30000$ \\
\hline
\end{tabular}

\section{CONCLUSIONS}

A turbocharging system is an integral part of a large Main Engine. The main components of which being the turbocharger and the air cooler. The turbocharger utilises the energy contained in the exhaust gases, of the Main engine to compress the air, temperature of which may rise to 200 dges C, required for combustion of the fuel in the Main engine cylinder. The compressed air is cooled in an air cooler before 
being sent to the engine cylinder, the air outlet temperature at the cooler outlet cooled down to 40 degs $C$. The turbocharger must run at its optimum efficiency to ensure efficient operation of the Main engine. The Kongsberg engine simulator at AMC was utilised to study the impact of the defective turbocharging system on the safety of the Mai Engine. This was done by running the engine at its normal speed of 74 RPM, under loaded condition. For the present study, two malfunctions of the turbocharging system were introduced to look at its effect on the operation of the Main Engine. These included one each on the air side and exhaust side of the turbocharger. The first malfunction introduced was a dirty air filter. It was seen that this malfunction did not hamper, the operation of the engine to a great degree. There was no drop in the RPM of the Main engine, only a marginal rise in the pressure drop across the filter and the temperature of exhaust gas after the turbocharger. The second malfunction involved a dirty exhaust inlet grid to the turbocharger. This condition had a major impact on the exhaust gas cylinder outlet temperature which rose by about $50 \%$. This also led to an increase in the cylinder liner and cylinder cover temperature to its alarming levels. After 11 minutes of running the Main Engine slowed down automatically, as per the safety provision provided by the engine manufacturer. Hence it is important to avoid this condition by carrying out the Planned Maintenance and periodic inspection of the exhaust manifold and ensure that the inlet grid is always clean and free from any coke deposits. Also, the turbocharging system must be reliable. With the help of a Fault Tree analysis and developing a Reliability Block Diagram, an equation was established, using which the Reliability of the Turbocharging, hence the reliability of the Main engine may be computed.

\section{FUTURE WORK}

Malfunctions of turbocharger compressor failure, turbine failure, failure of rotor bearings, and failure of air cooler to be considered to see its impact on the Main Engine operation. The study can be employed to other sub-systems of the main engine to establish a safe and reliable Main Engine at sea.

\section{REFERENCES}

1. Anantharaman, M., Islam, R., Khan, F., Garaniya, V., Lewarn, B.: Data Analysis to Evaluate Reliability of a Main Engine. TransNav, the International Journal on Marine Navigation and Safety of Sea Transportation. 13, 2, 403-407 (2019). https://doi.org/10.12716/1001.13.02.18.
2. Anantharaman, M., Islam, R., Khan, F., Garaniya, V., Lewarn, B.: Emergency preparedness for management of main propulsion engine failure on a bulker during harsh weather at sea. Safety in Extreme Environments. 2, 1, 103-111 (2020). https://doi.org/10.1007/s42797-01900014-5.

3. Anantharaman, M.P., Khan, F., Garaniya, V., Lewarn, B.: A holistic approach to reliability and safety on the operation of a main propulsion engine subjected to a harsh working environment. In: Proceedings of the 3rd Workshop and Symposium on Safety and Integrity Management of Operations in Harsh Environments (CRISE3). pp. 1-6 Memorial University Newfoundland, Canada (2017).

4. A/S, M. A. N.-B. W. D.: MAN B\&W 50-90 MC/MCE Engines / Instruction manual / Volume I: "Operation" M.A.N.-B\&W DIESEL A/S. (2017).

5. Australian Transport Safety Bureau: Independent investigation into the equipment failure on board the Australian registered bulk carrier Goliath. (2003).

6. Berdnikov, L.A., Pikulkin, A.A., Korchazhkin, M.G., Bazhan, P.I., Zakharov, L.A.: Study of factors affecting the reliability of turbochargers. IOP Conference Series: Materials Science and Engineering. 386, 012024 (2018). https://doi.org/10.1088/1757-899x/386/1/012024.

7. Bose, D., Ghosh, G., Mandal, K., Sau, S.P., Kunar, S.: Measurement and Evaluation of Reliability, Availability and Maintainability of a Diesel Locomotive Engine. International Journal of Scientific and Research Publications (IJSRP). 3, 9, (2013).

8. Čepin, M.: Reliability Block Diagram. In: Čepin, M. (ed.) Assessment of Power System Reliability: Methods and Applications. pp. 119-123 Springer London, London (2011). https://doi.org/10.1007/978-0-85729-688-7_9.

9. Islam, R., Anantharaman, M., Khan, F., Garaniya, V.: Reliability Assessment of a Main Propulsion Engine Fuel Oil System- What are the Failure-prone Components? TransNav, the International Journal on Marine Navigation and Safety of Sea Transportation. 13, 2, 415420 (2019). https://doi.org/10.12716/1001.13.02.20.

10. Knežević, V., Orović, J., Stazić, L., Čulin, J.: Fault Tree Analysis and Failure Diagnosis of Marine Diesel Engine Turbocharger System. Journal of Marine Science and $\begin{array}{llll}\text { Engineering. } & \text { 8, }\end{array}$ https://doi.org/10.3390/jmse8121004.

11. L. Mitsui Engineering Shipbuilding Co. Japan: Mitsui Technical Documentation Exhaust Gas Turbocharger Operating Manual. (2010).

12. Nnaji, O.E., Nkoi, B., Lilly, M.T., Le-ol, A.K.: Evaluating the Reliability of a Marine Diesel Engine Using the Weibull Distribution. Journal of Newviews in Engineering and Technology (JNET). 2, 2, 1-9 (2020).

13. Sabri, M., Immanuel Sibarani, A., Sabri, F.A.M., Geubrina, H.S.: Reliability investigation of steam turbine critical components. IOP Conference Series: Materials Science and Engineering. 801, 012125 (2020). https://doi.org/10.1088/1757-899x/801/1/012125.

14. Safie, F.M., Fuller, R.P.: NASA applications and lessons learned in reliability engineering. In: 2012 Proceedings Annual Reliability and Maintainability Symposium. pp. 1-5 (2012). https://doi.org/10.1109/RAMS.2012.6175423.

15. Waghmode, L.Y., Patil, R.B.: Reliability analysis and life cycle cost optimization: a case study from Indian industry. International Journal of Quality \& Reliability Management. 33, 3, 414-429 (2016). https://doi.org/10.1108/IJQRM-11-2014-0184. 